ks. Zdzisław Janiec

\title{
Troska o celebrację eucharystyczną w świetle adhortacji apostolskiej Sacramentum caritatis Ojca Swiętego Benedykta XVI
}

Adhortacja apostolska Sacramentum caritatis ${ }^{1}$ jest owocem synodu biskupów poświęconego Eucharystii, jaki odbył się w Rzymie jesienią 2005 roku na zakończenie Roku Eucharystii ogłoszonego jeszcze przez Jana Pawła II. Ojciec Święty Benedykt XVI z właściwą teologowi precyzją dokładnie określił cel opublikowanego w lutym 2007 roku dokumentu: „by lud chrześcijański pogłębił więź istniejącą pomiędzy tajemnicą eucharystyczną, akcją liturgiczną oraz nową służbą duchową wynikającą z sakramentu Eucharystii jako sakramentu miłości” (adhort. apost. Sacramentum caritatis, 5). Spośród tych trzech wymiarów Eucharystii („tajemnica”, ,akcja liturgiczna” oraz „nowa służba") w niniejszej refleksji chciałbym skoncentrować się jedynie na zawartych w adhortacji wskazaniach dotyczących samej akcji liturgicznej, w której uobecnia się „tajemnica” będąca źródłem „nowej służby duchowej”.

Przewodniczenie eucharystycznej „akcji liturgicznej” należy przecież do istotnych powinności każdego prezbitera. Skoro - zgodnie ze słowami Benedykta XVI - „kapłan przede wszystkim jest sługą, [...] który jako posłuszne narzędzie w rękach Chrystusa odsyła do Niego", a ta rzeczywistość „wyraża się szczególnie w pokorze, z jaką kapłan przewodzi liturgii” (adhort. apost. Sacramentum caritatis, 23), to trzeba podejmować refleksję nad sposobem sprawowania liturgii Eucharystii. Refleksja ta wydaje się tym bardziej potrzebna, że w słowach adhortacji można dostrzec pewną przestrogę przed zawsze możliwym zafałszowaniem kapłańskiej posługi. Przestrogę tę odnajdziemy m.in. w bardzo zdecydowanym sformułowaniu Benedykta XVI: „Cała ich posługa nigdy nie powinna wynosić na pierwszy plan ich samych lub ich opinii, ale Chrystusa. Każda próba stawiania siebie w centrum celebracji liturgicznej sprzeciwia się tożsamości kapłańskiej” (adhort. apost. Sacramentum caritatis, 23).

${ }^{1}$ Benedykt XVI, Posynodalna adhortacja apostolska Sacramentum caritatis, Watykan 2007, ogłoszona w Rzymie 22 lutego 2007 w święto Katedry św. Piotra Apostoła. 
Wobec tego niezwykle istotnym zadaniem nie tylko biskupów, ale również każdego prezbitera, któremu Kościół powierzył przewodniczenie Eucharystii, będzie troska o „transparentność”, „przejrzystość” celebracji eucharystycznej, tak aby w Eucharystii poprzez ludzką rzeczywistość osób, znaków, gestów i formuł jej uczestnicy mogli dostrzec przychodzącego do człowieka zmartwychwstałego Pana. Formułując odpowiedź na pytanie o to, na czym polega troska o celebrację Eucharystii w świetle wspomnianej adhortacji apostolskiej Benedykta XVI, należy zwrócić uwagę na trzy zagadnienia, które zarazem wyznaczają strukturę artykułu:

1. Troska o ars celebrandi.

2. Troska o głębię celebracji mszy świętej (wybrane części).

3. Troska o czynne uczestnictwo w Eucharystii.

\section{Troska o ars celebrandi}

Ars celebrandi można przetłumaczyć jako sztuka sprawowania mszy świętej. W ars celebrandi chodzi nie tylko o odpowiedź na pytanie: ,jak” sprawować liturgię, aby była ona piękna, ale „czym jest to”, co sprawujemy². „Piękno nie jest więc jedynie czynnikiem dekoracyjnym liturgii - napisał Benedykt XVI - lecz jest ono jej elementem konstytutywnym, gdyż jest atrybutem samego Boga i Jego objawienia" (adhort. apost. Sacramentum caritatis, 35). Według Papieża ars celebrandi wypływa z „wiernego posłuszeństwa wobec norm liturgicznych" (adhort. apost. Sacramentum caritatis, 38). Właściwie sprawowana liturgia została określona przez papieża „pierwszym warunkiem" sprzyjającym uczestnictwu i ułatwiającym uczestnictwo wiernych w tajemnicy Eucharystii (por. adhort. apost. Sacramentum caritatis, 38). Nie można zatem oddzielać sposobu celebrowania od pełnego, czynnego i owocnego uczestnictwa wszystkich wiernych w Eucharystii - w stwierdzeniu tym odnajdujemy niezwykle głęboki motyw pastoralny zachęcający duszpasterzy do wierności przepisom liturgicznym. Oczywiście, nie jest to motyw jedyny. W wielu innych dokumentach Kościół podkreślał, że Eucharystia nie jest własnością żadnego z jej szafarzy, a sposób jej sprawowania jest określany przez Kościół. Dlatego świadome lekceważenie liturgicznych wskazań Kościoła może niekiedy być znakiem nawet słabej wiary kapłana w sprawowaną tajemnicę. „Czujność i posłuszeństwo wobec właściwej struktury obrzędu wyrażają zrozumienie charakteru Eucharystii jako niewysłowionego daru i objawiają wolę celebransa przyjęcia go w posłusznej wdzięczności" (adhort. apost. Sacramentum caritatis, 40).

\footnotetext{
${ }^{2}$ Zob. Z. JANIEC, Komunikacyjny wymiar liturgii, Sandomierz 2006, s. 327.
} 
Sprawowanie liturgii eucharystycznej należy do całego ludu Bożego, ale - jak pisze papież Benedykt XVI - „w odniesieniu do poprawnego ars celebrandi wyjątkowe zadanie przypada tym, którzy otrzymali sakrament święceń”, a wśród nich szczególna odpowiedzialność spoczywa na biskupie diecezjalnym (adhort. apost. Sacramentum caritatis, 39). Co więcej, papież podkreśla, że wierność identycznym obrzędom i tekstom liturgicznym podczas sprawowania Eucharystii jest znakiem i wyrazem jedności wspólnot celebrujących ze swoim biskupem, a przez niego z całym Kościołem. W tym kontekście pojawia się bardzo znamienne stwierdzenie, które zostało sformułowane bardzo jasno: „W szczególności, wzywam, by uczyniono wszystko, co należy, by celebracje liturgiczne sprawowane przez biskupa w kościele katedralnym odbywały się z pełnym uszanowaniem ars celebrandi, tak by mogły być uznane za wzór dla wszystkich kościołów rozsianych na terytorium diecezji” (adhort. apost. Sacramentum caritatis, 39).

Aby jedność Kościoła znalazła swój wyraz w szacunku dla ars celebrandi w sprawowaniu Eucharystii, nie wystarczy prosta zewnętrzna wierność w przestrzeganiu przepisów liturgicznych. Eucharystia pozostaje znakiem jedności wtedy, kiedy zgromadzeni na jej sprawowaniu czynnie w niej uczestniczą. Dlatego szczególną powinnością wszystkich odpowiedzialnych za sprawowanie Eucharystii, a zwłaszcza biskupa diecezji, jest zabieganie o to, aby wszyscy ochrzczeni ,zdobywali coraz pełniejsze zrozumienie głębokiego sensu obrzędów i tekstów liturgicznych" (adhort. apost. Sacramentum caritatis, 39). Celebracja mszalna - pisze papież w adhortacji - „przynosi pożytek tam, gdzie kapłani oraz odpowiedzialni za duszpasterstwo liturgiczne starają się, by obowiązujące księgi liturgiczne i stosowne normy były znane, wskazując na bogactwa Ogólnego wprowadzenia do Mszału Rzymskiego oraz Wprowadzenia do czytań mszalnych. Zakłada się, że we wspólnotach kościelnych są one znane i szanowane, choć bywa, że tak nie jest" (adhort. apost. Sacramentum caritatis, 40). Postulat katechezy mistagogicznej, czyli wprowadzającej w głębsze rozumienie i przeżywanie znaków liturgicznych staje się naturalną konsekwencją refleksji prowadzonej w papieskiej adhortacji.

\section{KSIĘGI I ZNAKI LITURGICZNE}

W ars celebrandi dużą rolę przypisuje się księgom liturgicznym oraz znakom i gestom liturgicznym. Wśród ksiąg liturgicznych trzeba zwrócić uwagę m.in. na mszał i lekcjonarz, w oparciu o które jest celebrowana liturgia eucharystyczna. Niektóre z używanych formuł liturgicznych czy tekstów, zwłaszcza ze Starego Testamentu, mogą brzmieć nieco archaicznie i nie do końca zrozumiale (do takich formuł można zaliczyć np. wiele zwrotów obec- 
nych w modlitwie eucharystycznej, które dzisiaj nie są używane w języku potocznym, np. „Zaprawdę godne to i sprawiedliwe, słuszne i zbawienne, abyśmy...”). Interesująca jest uwaga Benedykta XVI, że „w rzeczywistości są to teksty, w których są zawarte bogactwa chroniące i wyrażające wiarę oraz drogę Ludu Bożego w ciągu dwóch tysięcy lat jego historii” (adhort. apost. Sacramentum caritatis, 40). Wydaje się, że obserwacja ta pragnie przestrzec przed pokusą prostego uwspółcześnienia tekstów liturgicznych odrywającego je od wielowiekowej tradycji.

Do znaków i gestów liturgicznych należą m.in. słowa i śpiewy, gesty i milczenie ${ }^{3}$, ruchy ciała, kolory liturgiczne oraz paramenty. Ta różnorodność znaków i gestów kryje w sobie - jak zauważył papież - „różnorodność środków komunikacji, które prowadzą do zaangażowania się całej ludzkiej istoty" (adhort. apost. Sacramentum caritatis, 40). Trzeba przyznać, że te znaki i gesty nie zawsze pozostają zrozumiałe same w sobie dla współczesnego człowieka ze względu na fakt, iż nie znajdują swojego miejsca w codziennym życiu lub też nieco inne znaczenie im się dzisiaj przypisuje. Niemniej również i one wyrastają z wielowiekowej tradycji i dlatego nie można łatwo z nich rezygnować. Odpowiednie wyjaśnienie ich sensu, czyli katecheza liturgiczna sprawi, że - w myśl adhortacji Benedykta XVI - posługiwanie się nimi „w określonym porządku i w czasie liturgii” przekaże i zangażuje „wiernych bardziej niż sztuczne, niestosowne dodatki” (adhort. apost. Sacramentum caritatis, 40).

\section{SZTUKA SAKRALNA}

$\mathrm{Z}$ ars celebrandi wiąże się sztuka sakralna. W praktyce spotykamy się z dwoma wyrażeniami: „sztuka sakralna” i „sztuka liturgiczna”. Niekiedy tych pojęć używa się zamiennie. W obu przypadkach chodzi o sztukę przeznaczoną głównie do podstawowych celebracji liturgicznych, czyli o sztukę związaną z kultem składanym Bogu'

Benedykt XVI podkreśla, że „ważnym składnikiem sztuki sakralnej jest niewątpliwie architektura kościołów. Powinna ona zachować jedność poszczególnych elementów prezbiterium: ołtarza, krucyfiksu, tabernakulum, ambony, krzeseł. Należy też mieć świadomość, że celem architektury sakralnej jest dostarczenie Kościołowi, który sprawuje Mszę świętą, przestrzeni najbardziej dostosowanej do właściwego przebiegu czynności

${ }^{3}$ Milczenie jest częścią, momentem, elementem własnym każdej celebracji liturgicznej. Jest ono tak konieczne w celebracji, jak potrzebne jest słowo; por. R. FALsinI, Gesty $i$ słowa Mszy świętej, tłum. A. Porębski, Kraków 2005, s. 128-129.

${ }^{4}$ Por. A. DzIUbA, Sztuka sakralna w stużbie misterium Chrystusa, „Liturgia Sacra” 1 (2001) t. 1, s. 114; J. Plazaola, Arte sacro actual, Madrid 1965, s. 3-24. 
liturgicznych" (adhort. apost. Sacramentum caritatis, 41). Znajdujemy tutaj bardzo ważne wskazanie dla wszystkich architektów świątyń, a także dla proboszczów akceptujących poszczególne projekty. Przestrzeń dla celebracji liturgicznych musi przybliżać rzeczywistość celebrowaną5.

\section{IKONOGRAFIA RELIGIJNA}

Duże znaczenie dla celebracji eucharystycznej mają malarstwo i rzeźba. Zdaniem papieża „religijna ikonografia winna być nakierowana na sakramentalną mistagogię" (adhort. apost. Sacramentum caritatis, 41), to znaczy, że ma wpływać na pogłębienie i piękno celebracji. A zatem sztuka służąca czy to do wystroju kościoła, czy też do ozdoby naczyń sakralnych lub innych paramentów liturgicznych powinna wzbudzać zachwyt nad misterium Boga, przyczyniając się zarazem do piękna celebracji, w mniejszym stopniu koncentrując uwagę na samej sobie ${ }^{6}$.

\section{ŚPIEW LITURGICZNY}

Ars celebrandi domaga się również zwrócenia uwagi na śpiew liturgiczny. Eucharystyczna celebracja bez śpiewu całego zgromadzenia nie odpowiada w pełni swojej istocie ${ }^{7}$. W soborowej Konstytucji o liturgii świętej Sacrosanctum Concilium po raz pierwszy ${ }^{8}$ muzyka została określona jako integralna część uroczystej liturgii. To stwierdzenie podkreśla znaczenie śpiewu w liturgii, który przestaje być tylko elementem upiększającym celebracje eucharystyczne (por. 112) ${ }^{9}$. Śpiew w liturgii jest często związany z jej tekstami (słowami), stąd jest on nieodzowny (np. werset Alleluja winien być zawsze śpiewany ${ }^{10}$ ). Dlatego wspomniana Konstytucja o liturgii świętej wzywa do tego, aby „troskliwie pielęgnować religijny śpiew ludowy, tak aby głosy wiernych mogły rozbrzmiewać podczas nabożeństw, a nawet w czasie czynności liturgicznych” (118). Papież Benedykt XVI przypomina, że „śpiew, jako element liturgiczny, winien być włączony we właściwą formę celebracji. [...] wszystko - tekst śpiewu, melodia i wykonanie - powinno

${ }^{5}$ Por. W. BARTocha, Architektura w stużbie liturgii, „Anamnesis” 13 (2007) nr 50, s. 113.

${ }^{6}$ Por. Ogólne Wprowadzenie do Mszału Rzymskiego, nr 319 -351.

${ }^{7}$ Por. R. FAlsini, Gesty i stowa Mszy Świętej, dz. cyt., s. 124.

${ }^{8}$ Konstytucja ta nie była pierwszym dokumentem, który podejmował tematykę muzycznoliturgiczną. Oprócz niej były następujące dokumenty: PIUs X, Motu proprio o muzyce sakralnej (1903), Konstytucja apostolska Divini cultus sanctitatem (1928), PIUS XII, enc. Mediator Dei (1947) i enc. Musicae sacrae disciplina (1955), oraz Święta Kongregacja ObrzęDów, Instrukcja O muzyce sakralnej i liturgii świętej (1958).

${ }^{9}$ Por. J. Stefański, Liturgia dla każdego, Gniezno 1995, s. 25.

${ }^{10} \mathrm{~W}$ przypadku, gdy nie śpiewa się alleluja, można je opuścić - por. Ogólne Wprowadzenie do Mszału rzymskiego, nr 63. 
odpowiadać znaczeniu celebrowanej tajemnicy, poszczególnym częściom obrzędu oraz okresowi liturgicznemu" (adhort. apost. Sacramentum caritatis, 42) ${ }^{11}$. Wśród wielu kierunków muzyki sakralnej papież wskazał na chorał gregoriański, stwierdzając, że domaga się on na nowo odpowiedniego dowartościowania jako „właściwy dla liturgii rzymskiej” (adhort. apost. Sacramentum caritatis, 42) ${ }^{12}$.

\section{Troska o głębię celebracji liturgicznej (wybrane części)}

Postępując za myślą Benedykta XVI, w kolejnej części trzeba zwrócić uwagę „na pewne części celebracji eucharystycznej, jakie w naszych czasach wymagają specyficznej troski dla zachowania wierności głębokiemu zamierzeniu odnowy liturgicznej" (adhort. apost. Sacramentum caritatis, 43). Zastanawiające jest użyte przez Ojca Świętego podkreślenie „w naszych czasach", które sugeruje, że sprawy, które w adhortacji podejmuje, pomimo swej pozornej oczywistości są warte przypomnienia ze względu na swoją aktualność. Znamienne jest również odwołanie się do ,zamierzenia odnowy liturgicznej”, która nie wyczerpuje się wyłącznie w zewnętrznej odnowie rytu mszalnego. Adhortacja apostolska Sacramentum caritatis podejmuje refleksję zaledwie nad kilkoma wybranymi elementami celebracjami Eucharystii, a są to: liturgia słowa, homilia, przygotowanie darów, modlitwa eucharystyczna, znak pokoju, udzielanie i przyjmowanie Eucharystii oraz rozesłanie. Dlaczego adhortacja dokonuje takiego właśnie wyboru? W tekście dokumentu nie znajdujemy precyzyjnej odpowiedzi. Można jednak przypuszczać, że w tych wybranych elementach najłatwiej można dostrzec więź pomiędzy tajemnicą uobecnianą, celebracją i wezwaniem do służby w świecie (ukazanie owej więzi było zasadniczym celem dokumentu), a równocześnie głębsze celebrowanie wybranych części stanowi chrześcijańską odpowiedź na wyzwania współczesnego czasu.

\section{LITURGIA SEOWA}

Kilka twierdzeń pojawiających się w tej części dokumentu ma charakter apelatywny, np. „żywo polecam, by przykładano wielką wagę do czytania podczas liturgii słowa Bożego [...]. Nie zapominajmy nigdy, że «gdy w Kościele czyta się Pismo święte, sam Bóg przemawia do swego ludu, a Chrystus, obecny w swoim słowie, zwiastuje Ewangelię»" (adhort. apost. Sacramentum caritatis, 45). Skądinąd prawdy, do których odnoszą

${ }^{11}$ Ideał nie polega na tym, aby śpiewać wszystko i zawsze. Każdy śpiew we mszy świętej ma własne znaczenie i wyraża szczególne uczucia; por. R. FALSINI, Gesty i słowa Mszy Świętej, dz. cyt., s. 126.

${ }^{12}$ Por. K. Matwiejuk, Chorat jako śpiew Kościoła, „Anamnesis” 13 (2007) nr 50, s. 95. 
się powyższe sformułowania, noszą znamiona oczywistości. Ich obecność w dokumencie tej rangi co adhortacja apostolska oraz sposób ich ujęcia wskazują, że przypomnienie o rzeczywistej obecności Chrystusa w słowie jest dzisiaj potrzebne. Podobnie można odczytać inne papieskie słowa zamieszczone w tym samym punkcie: „Chrystus nie przemawia w przeszłości, ale w naszej teraźniejszości, jako Ten, który jest obecny w czynności liturgicznej" (adhort. apost. Sacramentum caritatis, 45). Wydaje się zatem, że pierwszym wyrazem wierności soborowej odnowie liturgii będzie ożywienie wiary w realną możliwość słyszenia Boga. Konsekwencją tej wiary będzie dowartościowanie tej części mszy świętej, a także dokładanie starań, aby proklamujący słowo podczas liturgii byli odpowiednio przygotowani zarówno od strony technicznej, jak i biblijno-liturgicznej ${ }^{13}$.

Potrzeba czynnego udziału w liturgii słowa domaga się studiowania i poznawania Pisma Świętego przez wszystkich wiernych. Ojciec Święty przywołuje twierdzenie św. Hieronima: „nieznajomość Pisma świętego jest nieznajomością Chrystusa" (45). Wielką pomocą w głębszym przeżywaniu mszalnej liturgii słowa mogą być różnego rodzaju inicjatywy duszpasterskie, celebracje słowa, modlitewna lektura perykop biblijnych (lectio divina), a także modlitwa liturgią godzin (por. adhort. apost. Sacramentum caritatis, 45).

\section{HoMiLia}

Znamienne jest, że adhortacja apostolska Sacramentum caritatis zagadnienie homilii ujmuje w osobnym punkcie, chociaż w istocie swojej w strukturze celebracji Eucharystii stanowi ona część liturgii słowa. Być może stało się tak dlatego, żeby z jednej strony podkreślić znaczenie samych czytań mszalnych, z drugiej natomiast wyjątkowe miejsce homilii. Homilia liturgiczna jest to kaznodziejski przekaz słowa Bożego zawartego w Piśmie Świętym w kontekście sakramentalnej obecności Chrystusa ${ }^{14}$. „Jako część samej liturgii zaleca się bardzo homilię, w której z biegiem roku liturgicznego wykłada się, na podstawie tekstów świętych, tajemnice wiary i zasady życia chrześcijańskiego" (SoBór WATYKAŃSKI II, konst. Sacrosanctum Concilium, 52). Zadaniem homilii jest „dopomagać pełnemu zrozumieniu oraz oddziaływaniu słowa Bożego na życie wiernych" (adhort. apost. Sacramentum caritatis, 46). Uwagę zwraca określenie podwójnego celu homilii. Nie wystarczy, że będzie ona wyjaśniała odczytane podczas liturgii słowa perykop biblijnych. Pomagając wiernym w zrozumieniu przedłożonych przez Kościół fragmentów Pisma Świętego, homilia powinna prowadzić słuchaczy do jakichś decyzji dotyczących ich codziennego życia. Jeśli homi-

\footnotetext{
${ }^{13}$ Por. R. FAlsini, Gesty $i$ stowa Mszy świętej, dz. cyt., s. 54.

${ }^{14}$ Zob. Z. JANIEC, Homilia liturgiczna, „Anamnesis” 11 (2005) nr 41, s. 138-140.
} 
lia takich decyzji nie rodzi, wówczas mamy do czynienia z sytuacją, którą w potocznym języku nazywa się „mówieniem ponad głowami”.

W tym kontekście Benedykt XVI apeluje o poprawienie jakości wygłaszanych homilii. Homilia powinna być „dokładnie przygotowana opierając się na stosownej znajomości Pisma Świętego" (adhort. apost. Sacramentum caritatis, 46). „Należy unikać homilii ogólnych i abstrakcyjnych”, tak aby „głoszone Słowo Boże było ściśle powiązane z celebracją sakramentalną i z życiem wspólnoty" (adhort. apost. Sacramentum caritatis, 46). Treść do homilii powinno się czerpać z magisterium Kościoła w oparciu o cztery „filary” określone przez Katechizm Kościoła Katolickiego, czyli: „wyznanie wiary, celebracja misterium chrześcijańskiego, życie w Chrystusie i modlitwa chrześcijańska" (adhort. apost. Sacramentum caritatis, 46). To jest ważna uwaga, gdyż dążenie do uniknięcia homilii abstrakcyjnych może niekiedy doprowadzić do przekazu treści bliskich życiu codziennemu, ale zdroworozsądkowych, które nie potrzebują autorytetu słowa Bożego.

Te bardzo proste wskazania każdemu, kto podejmuje się posługi słowa, powinny dać wiele do myślenia. Trzeba mieć świadomość, że adhortacja jest owocem obrad synodu biskupów przybywających z całego świata, a każdy z nich wnosi w obrady doświadczenie swojego własnego Kościoła. Spostrzeżenie o „unikaniu homilii abstrakcyjnych” wyrasta zapewne z głosów biskupów dostrzegających pewne problemy w łonie swoich diecezji.

\section{PRZYGotowanie DARÓW}

Przygotowanie darów jest częścią liturgii mszy świętej mającą charakter przygotowawczy w stosunku do liturgii eucharystycznej. Przez wiele wieków chrześcijanie przynosili do ołtarza chleb i wino razem z innymi darami. Dokument Benedykta XVI kwestionuje możliwe potraktowanie tego obrzędu jako swego rodzaju „ "przerwy» pomiędzy liturgią słowa a liturgią eucharystyczną" (adhort. apost. Sacramentum caritatis, 47). Być może takie rozumienie tego obrzędu istnieje w niektórych środowiskach. Ten gest złożenia na ołtarzu darów ma swoje głębokie znaczenie: „w chlebie i winie, jakie zanosimy na ołtarz, Chrystus Odkupiciel przyjmuje całe stworzenie, by je przemienić i ofiarować Ojcu" (adhort. apost. Sacramentum caritatis, 47). W ten sposób zostają dowartościowane dwa elementy ludzkiej egzystencji: praca i samo życie człowieka w świecie stworzonym ${ }^{15}$. Jednak po to, aby obrzęd ten nie zatrzymał się na poziomie zewnętrznych znaków, ale zaangażował serce człowieka, potrzeba, aby uczestniczący w Eucharystii człowiek przyjmował świat stworzony jako dar od Boga, a swoją pracę i całe swoje istnienie przeżywał jako dar składany Bogu. Formacji liturgicznej do

\footnotetext{
${ }^{15}$ Por. R. Falsini, Gesty i stowa Mszy świętej, dz. cyt., s. 57.
} 
celebrowania tego obrzędu powinna zatem towarzyszyć formacja do życia jako daru składanego Bogu z samego siebie w codzienności. W momencie składania na ołtarzu chleba i wina człowiek wraz z nimi powinien składać wszystko, co niesie życie jego i życie innych, a więc trud pracy, troski rodzinne, radości, a także ból i cierpienie. To wszystko w oczach Bożych poprzez obrzęd przygotowania darów nabiera szczególnej wartości, gdyż „poprzez celebrację eucharystyczną jest zjednoczone z ofiarą odkupieńczą Chrystusa" (adhort. apost. Sacramentum caritatis, 47).

\section{MODLITWA EUCHARYSTYCZNA}

Modlitwa eucharystyczna stanowi centralną część całej celebracji Eucharystii, jest jej „ośrodkiem i szczytem” (adhort. apost. Sacramentum caritatis, 48). Bez niej msza święta nie miałaby sensu ${ }^{16}$. Benedykt XVI przypomina podstawowe elementy każdej modlitwy eucharystycznej, tj. dziękczynienie, aklamację, epiklezę, narrację o ustanowieniu Eucharystii, konsekrację, anamnezę, ofiarowanie, modlitwy wstawiennicze oraz końcową doksologię. Papież zachęca do pogłębienia rozumienia tekstów modlitw eucharystycznych zawartych w mszale, które - jak sam podkreśla - „,zostały nam przekazane przez żywą tradycję Kościoła i wyróżniają się nieprzebranym teologicznym oraz duchowym bogactwem" (adhort. apost. Sacramentum caritatis, 48). W tekście adhortacji uwagę zwraca zdecydowanie wskazana przez papieża potrzeba dostrzeżenia więzi „pomiędzy wezwaniem Ducha Świętego a słowami ustanowienia” (adhort. apost. Sacramentum caritatis, 48). Świadomość tej więzi jest istotna, bowiem modlitwa do Ojca o zesłanie Ducha Świętego (epikleza) połączona ze słowami Jezusa z wieczernika: „Bierzcie i jedzcie [...], bierzcie i pijcie” tworzy zjawisko anamnezy, tj. uobecnienie męki i śmierci Chrystusa (hodie).

\section{ZNAK POKOJU}

„Eucharystia ze swej natury jest sakramentem pokoju” (adhort. apost. Sacramentum caritatis, 49). Pozdrowienie pokoju rozbrzmiewa kilka razy podczas celebracji liturgicznej ${ }^{17}$. Istnieje jednak w liturgii Eucharystii jeden szczególny moment, w którym przekazywany jest znak pokoju. „Bez wątpienia chodzi o znak mający szczególną wartość” (adhort. apost. Sacramentum caritatis, 49) - podkreśla Benedykt XVI. W dzisiejszej dobie obciążonej konfliktami i wojnami nabiera on dodatkowo wyjątkowego znaczenia. Obecnie Kościół dostrzega szczególną tęsknotę człowieka za pokojem i dlatego prowadzi go ku Bogu, który ,jest naszym pokojem” (Ef 2, 14),

\footnotetext{
${ }^{16}$ Por. tamże, s. 59.

${ }^{17}$ Por. tamże, s. 118.
} 
równocześnie modląc się do Boga o dar pokoju dla siebie i całej rodziny ludzkiej. Benedykt XVI wskazuje jednak na możliwą praktykę celebrowania tego obrzędu, która przyjmując „nadmierny wyraz” i „wzbudzając pewne zamieszanie”, prowadzi do wypaczenia jego najgłębszego sensu, jakim jest przekazanie pokoju od Tego, który znajduje się na ołtarzu. O jakie praktyki może tutaj chodzić? Należy przypuszczać, że może chodzić m.in. o spotykane także w polskich zgromadzeniach eucharystycznych przekazywanie znaku pokoju przez podchodzenie każdego z uczestników liturgii do wszystkich pozostałych. Istotnie, może wtedy powstać wrażenie, że przekazywany pokój pochodzi wzajemnie od uczestników liturgii, nie zaś od Tego, który jest źródłem wszelkiego pokoju. Jakkolwiek wspomniana praktyka w dokumencie nie została zakwestionowana expressiss verbis, to jednak wyraźnie został sformułowany postulat pewnej „powściągliwości w stosowaniu tego gestu, [...] ograniczając się na przykład do przekazania tego znaku jedynie tym, którzy stoją obok" (adhort. apost. Sacramentum caritatis, 49) ${ }^{18}$.

\section{UDZIELANIE I PRZYJMOWANIE KOMUNII ŚWIĘTEJ}

Powtórzonemu w każdej relacji z ostatniej wieczerzy zaproszeniu Jezusa: „Bierzcie [...], jedzcie [...], pijcie” odpowiada w celebracji Eucharystii obrzęd komunii świętej. Problem udzielania i przyjmowania komunii świętej również został zauważony w papieskiej adhortacji. Nie dziwi odwołanie się do istniejących norm dotyczących właściwej praktyki, zawartych zwłaszcza w dokumentach ostatnio ogłoszonych wraz z zachętą do ich przestrzegania. Zwraca uwagę wskazanie na znaczenie chwili dziękczynienia po przyjęciu komunii świętej, która może być wypełniona nie tylko wspólnym śpiewem, ale także trwaniem w ciszy i osobistej modlitwie, „w milczącym skupieniu" (adhort. apost. Sacramentum caritatis, 50). Natomiast zastanawiająco brzmi papieski apel wypowiedziany w kontekście refleksji nad przyjmowaniem i udzielaniem komunii świętej: „Proszę wszystkich, w szczególności wyświęconych szafarzy [...], by uczynili wszystko, aby ten gest w swej prostocie odpowiadał znaczeniu osobistego spotkania z Panem Jezusem w sakramencie" (adhort. apost. Sacramentum caritatis, 50). Czy w ogóle taki apel jest potrzebny? Jeżeli pojawia się w dokumencie, to widocznie zaistniały okoliczności, które go spowodowały. Widocznie jest możliwe, że obrzęd przyjęcia komunii świętej w świadomości niektórych traci swój najgłębszy sens, stając się gestem, któremu nadaje się inne znaczenie. Jakie? Trudno tu spekulować (może chodzi np. o podkreślane w niektórych środowiskach znaczenia wspólnego zasiadania przy jednym stole i wspólnoty w wymiarze horyzontalnym). W każdym razie istotnym

\footnotetext{
${ }^{18}$ Por. tamże.
} 
dla katechezy liturgicznej będzie zwrócenie uwagi na potrzebę wyjaśnienia sensu przyjęcia komunii świętej, który przypomina adhortacja apostolska Sacramentum caritatis. Pogłębione wyjaśnienie sensu komunii świętej oraz warunków koniecznych do jej przyjęcia potrzebne jest również osobom znajdującym się w skomplikowanej sytuacji życiowej niepozwalającej na przystąpienie do sakramentów lub osobom innego wyznania czy innej religii (por. Sobór Watykański II, konst. Sacrosanctum Concilium, 50).

\section{ROZESEANIE: „ITE MISSA EST”}

Dokument zwraca uwagę, że ostatnie słowa celebracji „Ite missa est” „wyrażają związek pomiędzy sprawowaną Mszą świętą a chrześcijańską misją w świecie" (adhort. apost. Sacramentum caritatis, 51). Obrzęd ten zdaje się być niezwykle ważny w kontekście zasadniczego celu dokumentu, o którym już była mowa poprzednio: więzi pomiędzy celebrowaną tajemnicą, samą celebracją a służbą chrześcijanina. Liturgiczne „słowo pożegnania wyraża w sposób syntetyczny naturę misyjną Kościoła. Dlatego dobrze jest przy okazji dopomóc Ludowi Bożemu w pogłębieniu tego konstytutywnego wymiaru życia kościelnego" (adhort. apost. Sacramentum caritatis, 51). W tym kontekście adhortacja wysuwa postulat wprowadzenia „odpowiednich, zatwierdzonych tekstów modlitwy nad ludem oraz do końcowego błogosławieństwa, które wyjaśnią ten związek pomiędzy Mszą świętą a chrześcijańską misją" (adhort. apost. Sacramentum caritatis, 51).

\section{Troska o uczestnictwo w Eucharystii}

\section{UCZESTNICTWO WE MSZY ŚWIĘTEJ}

Słusznie Sobór Watykański II położył szczególny nacisk na czynne, pełne i owocne uczestnictwo całego ludu Bożego w celebracji eucharystycznej. Stąd aktualne jest wezwanie Konstytucji o liturgii świętej, by wierni nie uczestniczyli w liturgii eucharystycznej ,jak obcy i milczący widzowie”, ale by „w świętej czynności uczestniczyli świadomie, pobożnie i czynnie” (48). Czynne uczestnictwo polega nie tylko na zewnętrznym udziale w sprawowanych obrzędach, ale przede wszystkim na zaangażowaniu się w nie całym swoim jestestwem.

O czynnym uczestnictwie Benedykt XVI pisze tak: „winno być ono rozumiane w sensie głębszym, począwszy od większej świadomości tajemnicy, która jest celebrowana, aż do jej związku z codzienną egzystencją" (adhort. apost. Sacramentum caritatis, 52). Przypomina też warunki niezbędne dla czynnego uczestnictwa w celebracji Eucharystii. Jednym z nich jest duch ciągłego nawracania się. Sprzyja mu skupienie i milczenie przynajmniej 
przez chwilę przed rozpoczęciem liturgii, post i jeśli to jest konieczne, spowiedź sakramentalna. Ponadto papież zachęca do jednoczenia się z Chrystusem w tzw. komunii duchowej, gdy nie można przystąpić do komunii sakramentalnej (por. adhort. apost. Sacramentum caritatis, 55) ${ }^{19}$.

\section{ZJAWISKO INKULTURACJI MSZALNEJ}

Z zagadnieniem czynnego uczestnictwa w Eucharystii wiąże się problem inkulturacji celebracji mszy świętej. Fenomen ten polega na wprowadzeniu pewnych adaptacji do różnych okoliczności życia i różnych kultur. Chodzi o to, aby tę samą tajemnicę Chrystusa celebrować w różnych sytuacjach kulturowych. Bóg pragnie dotrzeć do człowieka w jego konkretnych życiowych uwarunkowaniach (por. adhort. apost. Sacramentum caritatis, 54). Dokonując owych adaptacji, należy jednak mieć na uwadze wskazania zawarte w dokumentach Kościoła (por. adhort. apost. Sacramentum caritatis, 54).

\section{MALE I WIELKIE GRUPY CELEBRACYJNE}

W kontekście czynnego uczestnictwa adhortacja zajmuje się również zagadnieniem celebracji Eucharystii z udziałem wielu kapłanów i dużej liczby wiernych oraz celebracji z udziałem małych grup wiernych. Zasadniczo nie można celebrować mszy świętej bez zgromadzenia wiernych, ponieważ podmiotem celebracji jest zgromadzenie ludu Bożego pod przewodnictwem kapłana ${ }^{20}$. Z tego powodu należy unikać sprawowania mszy świętej przez pojedynczego kapłana bez udziału wiernych, chociaż w szczególnych okolicznościach jest to dopuszczalne.

Podejmując problem wielkich zgromadzeń eucharystycznych, Benedykt XVI zwraca uwagę na potrzebę odpowiedniego przygotowania miejsca takiej celebracji, by okoliczności zewnętrzne nie powodowały rozproszenia i umożliwiły pełne uczestnictwo koncelebransów i wszystkich wiernych (por. adhort. apost. Sacramentum caritatis, 61). Nawiązując zaś do celebracji międzynarodowych, postuluje dowartościowanie w nich języka łacińskiego, co oczywiście wymaga przynajmniej minimalnego przygotowania do udziału w nich zarówno wiernych świeckich, jak i duchownych (por. adhort. apost. Sacramentum caritatis, 62).

Podejmując zagadnienie celebracji Eucharystii w małych grupach, Benedykt XVI zwraca uwagę na potrzebę takiego ukształtowania świadomości jej uczestników, aby udział w niej nie rywalizował ani nie rozbijał wspólnoty Kościoła, ale służył jej jedności (por. adhort. apost. Sacramentum caritatis, 63).

\footnotetext{
${ }^{19}$ Por. Jan Pawee II, enc. Ecclesia de Eucharistia (17 kwietnia 2003), 34.

${ }^{20}$ Por. R. Falsini, Gesty i stowa Mszy świętej, dz. cyt., s. 32.
} 
Ponadto papieska adhortacja zwraca uwage na zagadnienie transmisji mszy świętej przez telewizję. Warto zacytować odnośny fragment w całości: „ktokolwiek korzysta z takiej transmisji, powinien wiedzieć, że w normalnych warunkach nie spełnia świątecznego obowiązku. Język obrazu bowiem przedstawia rzeczywistość, ale jej samej nie uobecnia. Jeśli jest bardzo godne pochwały to, że starsi i chorzy uczestniczą w świątecznej Mszy świętej transmitowanej przez radio czy telewizję, to nie można jednak tego powiedzieć o kimś, kto ze względu na te transmisje chciałby się zwolnić z pójścia do kościoła oraz uczestnictwa w celebracji eucharystycznej żywego Kościoła" (adhort. apost. Sacramentum caritatis, 57).

\section{Zakończenie}

Z przeprowadzonego powyżej studium wynikają następujące wnioski:

1. Papież jest zatroskany o ars celebrandi w celebracjach eucharystycznych. Troska ta spoczywa na całym ludzie Bożym, a wyrażać się winna w używaniu i poszanowaniu ksiąg liturgicznych, znajomości znaków, gestów i postaw liturgicznych. Nadto należy się zatroszczyć o sztukę sakralną i śpiew liturgiczny mające wpływ na celebrację liturgiczną.

2. Benedykt XVI widzi potrzebę troski o głębię celebracji eucharystycznej, a zwłaszcza niektórych jej części. Szczególną wagę przywiązuje do przygotowania proklamacji słowa Bożego, jakości głoszonych homilii, głębszej świadomości przemiany i ofiarowania złożonych darów, docenienia modlitw eucharystycznych, znaku pokoju, sposobu udzielania i przyjmowania komunii świętej oraz troski o chrześcijańską misję w świecie.

3. Ojciec Święty wypowiada troskę o uczestnictwo w liturgii mszalnej. Chodzi o czynne uczestnictwo, inkulturację mszalną i dowartościowanie wielkich i małych grup celebracyjnych przez kapłanów i wiernych.

Należy stwierdzić, że troska o celebrację Eucharystii wyrazi się przede wszystkim w podjęciu różnego rodzaju inicjatyw zmierzających do obudzenia i wzrostu wiary w Eucharystię. Wtedy będzie ona pobożnie sprawowana i intensywnie przeżywana zarówno przez duchownych, jak i świeckich (por. adhort. apost. Sacramentum caritatis, 94). 


\section{Summary}

The care of the Eucharistic celebration in the light of the Apostolic Exhortation Sacramentum caritatis of Benedict XVI

The article refers to Pope Benedict XVI's concern expressed in the Apostolic Exhortation Sacramentum Caritatis. The Pope puts emphasis on ars celebrandi which is to be duly performed by priests, deacons, and laymen.

Benedict XVI is also concerned about some parts of the liturgy of the Eucharist, among others, the liturgy of the Word. He also draws attention to active participation, inculturation and full appreciation of big and small celebration groups

According to the Holy Father, in order to make the Eucharistic celebration more perfect some initiative must be created to stimulate the growth of real faith in the Holy Eucharist. Thanks to these attempts the Holy Mass can be piously celebrated and intensively experienced. 